\title{
Behavioral aspects of waterbirds
}

\author{
B. Rubert ${ }^{\text {* (D), J. O. Branco }}$ (D), G. H. C. Barrillia (D), D. C. Melo ${ }^{a}$ (D) and A. P. Ferreira ${ }^{a}$ \\ aPrograma de Pós-graduação em Ecologia e Recursos Naturais, Universidade Federal de São Carlos - UFSCar, \\ Rodovia Washington Luís, Km 235, SP-310, CEP 13565-905, São Carlos, SP, Brasil \\ 'Laboratório de Biologia, Universidade do Vale do Itajaí - Univali, Rua Uruguai, 458, Centro, CEP 88302-901, Itajaí, SC, Brasil \\ *e-mail: barbara_rubert@hotmail.com
}

Received: June 10, 2019 - Accepted: August 20, 2019 - Distributed: February 28, 2021

(With 5 figures)

\begin{abstract}
Estuaries are used by waterbirds as foraging, resting and nesting sites, serving also as shelter for migratory birds. The dynamics of this avifauna in an aquatic environment may be associated with the differences of time of day, tide height, temperature, wind speed and use of the site by different species. This study had the objective of evaluating behavioral aspects of aquatic birds, relating the influence of environmental variables with their activities. Bird counts were performed at the mouth of two important rivers of the state of Santa Catarina, Brazil, during two-hour intervals throughout the day in monthly samplings between June (2015) and May (2016). A total of 44 species were recorded, ten of which were migratory. The most recorded behaviors were foraging and resting. The Kruskal-Wallis analysis indicated no significant difference in behavior between the sampling intervals. The Bray-Curtis similarity test resulted in three groups: 1) - species that foraged most of the time; 2) - species that rested most of the time; and 3) - same time in both activities. The Indicator Species Analysis showed that 17 species were associated with only one microhabitat and 15 species with more than one. The Canonical Correlation Analysis indicated that only tide height, temperature and rainfall variables were correlated with the behaviors performed and only the resting activity was positively correlated with all variables. This may be associated with thermoregulation and the ability of some species to stay in midlitoral at high tide. The results demonstrate that different waterbird species used the studied areas in different ways. Thus, the heterogeneity of microhabitats in an aquatic environment of extreme importance for the coexistence and maintenance of the diversity of waterbirds.
\end{abstract}

Keywords: behavior, waterbird, migratory birds, community ecology, estuaries, habitat use.

\section{Aspectos comportamentais de aves aquáticas}

\section{Resumo}

Estuários são utilizados por aves aquáticas como locais de forrageio, descanso e nidificação, servindo, também, como pontos de parada para aves migratórias. A dinâmica dessa avifauna em um ambiente pode estar associada a diferenças entre horários do dia, altura da maré, temperatura, velocidade do vento e uso do local. Esse trabalho teve o objetivo de avaliar aspectos comportamentais de aves aquáticas, relacionando a influência de variáveis ambientais com suas atividades. Amostragens mensais foram realizadas na foz de dois importantes rios do Estado de Santa Catarina, Brasil, entre junho de 2015 e maio de 2016, em intervalos de duas horas no decorrer do dia. Um total de 44 espécies foram registradas, dez das quais foram migratórias. Os comportamentos mais observados foram forrageio e descanso. A análise de Kruskall-Wallis não indicou diferenças significativas no comportamento entre os horários de amostragem. O teste de similaridade Bray-Curtis resultou em três agrupamentos: 1) - espécies que forragearam na maior parte do tempo; 2) - espécies que descansaram na maior parte do tempo; e 3) - mesma quantidade de tempo em ambas atividades. A Análise de Espécies Indicadoras mostrou que 17 espécies estiveram associadas com apenas um microhabitat e 15 espécies com mais de um. A Análise de Correlação Canônica indicou que apenas as variáveis maré, temperatura e precipitação foram significativamente correlacionadas com os comportamentos demonstrados e apenas a atividade de descanso foi positivamente correlacionada com as todas as variáveis. Isso pode estar associado com a termorregulação e com a habilidade de algumas espécies de permanecer no mediolitoral durante a maré cheia. Os resultados demonstram que diferentes espécies de aves aquáticas utilizaram as áreas estudadas de diferentes maneiras. Assim, a heterogeneidade de microhabitats em um ambiente aquático é de extrema importância para a coexistência e a manutenção da diversidade de aves.

Palavras-chave: comportamento, aves aquáticas, aves migratórias, ecologia de comunidades, estuários, uso de habitat. 


\section{Introduction}

The coastal environment is home to a high diversity of wader, marine and pelagic birds (Vooren and Brusque, 1999), including migrant species that leave their breeding grounds before the boreal winter and reach the Brazilian estuaries every year (Morrison, 1984). These ecosystems are influenced daily by the wind direction, tidal fluctuations and water quality (Schreiber and Burger, 2002; Hastie and Smith, 2006), providing the resident and migrant birds with diverse places for feeding, resting and nesting (Araújo et al., 2006; Loebmann and Vieira, 2006; Elliott et al., 2007).

Among the typical waterbird groups found along the Brazilian coast, the following are highlighted: Charadriiformes, composed predominantly of plovers (Charadriidae), sandpipers (Scolopacidae), gulls (Laridae) and terns (Sternidae). Other taxa that have a close ecological relationship with aquatic environments, such as egrets and herons (Pelecaniformes), mallets, ducks (Anseriformes), spoonbills (Threskiornithidae) and cormorants (Suliformes), are also found (Sick, 1997; Lopes et al., 2007; CBRO, 2015). These groups of birds are distributed unevenly along the environment (Blanco 1999) according to the heterogeneity of wetlands (Haig et al., 1998; Amezaga et al., 2002),

The study of bird behavior can provide basic information on ecological aspects of species in their environment. Changes in behavioural patterns may act as an indicator of environmental quality (Blanco, 1999). Factors that influence habitat selection, such as density, distribution, probability of detection, prey capture and competition (Maccarone and Parsons, 1994; Arengo and Baldassarre, 1999; Gawlik, 2002), as well as the disturbance generated by human presence, can interfere in the frequency and abundance of birds in coastal regions (Burger and Gochfeld, 1991; Barbieri et al., 2003; Barbieri and Pinna, 2005; Cestari, 2008). The observation of daily activity patterns of waterbird can be a tool to delineate their habitat use, types of behaviors and feeding sites (Ntiamoa-Baidu et al., 1998; Kasoma, 2000; Shimada, 2002; Yang et al., 2007; Pimenta et al., 2007; Branco et al., 2009; Zhou et al., 2010).

The Tijucas Bay, with its rivers Tijucas and Inferninho, presents high productivity and serves as a nursery site for several species (Medeiros, 2009). This locality is also considered one of the top tourist destinations of Santa Catarina (Brasil, 2004), making the habitats in its region susceptible to anthropogenic activities. Assuming that the variation of the richness, abundance and behavior of the waterbird community are associated to differences in time of day, environmental variables and habitat use by different species (Gawlik, 2002; Barbieri et al., 2003; Barbieri and Pinna, 2005; Cestari, 2008), this study aimed to evaluate the importance of these areas for the maintenance of the aquatic avifauna diversity, considering the different microhabitats found. For this, behavioral data of the local aquatic avifauna and its relation with the environmental variables, tidal height, temperature and wind velocity were analyzed.

\section{Material and Methods}

\subsection{Study area}

The mouths of the rivers Tijucas $\left(27^{\circ} 14^{\prime} 46.75^{\prime \prime} \mathrm{S}\right.$ $\left.48^{\circ} 36^{\prime} 48.45^{\prime \prime} \mathrm{W}\right)$ and Inferninho (27 $18^{\prime} 56^{\prime}$ ' S - 48 $\left.35^{\prime} 45^{\prime \prime} \mathrm{W}\right)$ are located at the Tijucas Bay, coastal region of Santa Catarina, Brazil (Figure 1). They have wide areas with muddy substract in the intertidal region, with presence of coarse sandbanks (Ghizoni Junior and Piacentini, 2010). The mouth of the Tijucas River has the greatest proportion of sand found in the Tijucas Bay, and just as in the mouth of the Inferninho River, silt is in greater proportion than clay (Schettini et al., 2010).

The local climate is humid subtropical, with rainfall evenly distributed throughout the year, average annual rainfall of $1.415 \mathrm{~mm}$, average temperature of $21.4{ }^{\circ} \mathrm{C}$ (Santa Catarina, 1986) and medium tidal height of $0.8 \mathrm{~m}$, ranging from $0.3 \mathrm{~m}$ to $1.2 \mathrm{~m}$ (Schettini, 2002).

\subsection{Methodology}

Sampling consisted of monthly bird counts in the mouths of the Tijucas and Inferninho rivers between June, 2015 and May, 2016, performed during two-hour intervals starting at 08:00 hours. The last count started at 16:00 hours. A total of 60 counts were performed at each site. Birds were identified, counted and had their behavior determined throughout $1.1 \mathrm{~km}$ long linear transects. To avoid recounting the same bird in the same transect, the flight or walking direction of birds in movement was determined between count points. Observations were made using binoculars $(10 \times 50)$. The scientific classification of species followed the Brazilian Committee of Ornithological Records (CBRO, 2015).

We considered four behavior categories: feeding (handling and swallowing prey), plumage maintenance (bath, drying and feather preening), rest (standing still or laid on the ground and supporting oneself with one leg with neck retracted with head between the wings), and socialization (agonistic behavior, agression or escapes) (Nunes and Piratelli, 2005; Herculano et al., 2013; Ebert et al., 2014), which were identified using the scan sampling method (Altmann 1974) and activity monitoring for 10 seconds (Fasola and Canova, 1993; Ntiamoa-Baidu et al., 1998).

Five microhabitats were identified in the mouth of the two rivers, based on the zonation of the macrozoobenthos (Castro and Huber, 2012; Stephenson and Stephenson, 1949): Superlitoral, area above the tidal influence corresponding to the strip of sand and sand banks; Midlitoral, zone flooded by the tides, composed by mud substrate; Pasture area, comprised by grass and shrubby vegetation for cattle grazing; Marsh, area with puddles formed by the invasion of the tide and rain, also composed by mud substrate; Inner bursting area, marine zone under the influence of waves until approximately 2 meters deep.

The environmental variables analyzed were: wind speed, tidal height, air temperature and precipitation. These data were collected from the database (Banco Nacional de Dados Oceanográficos - BNDO and Banco de Dados 

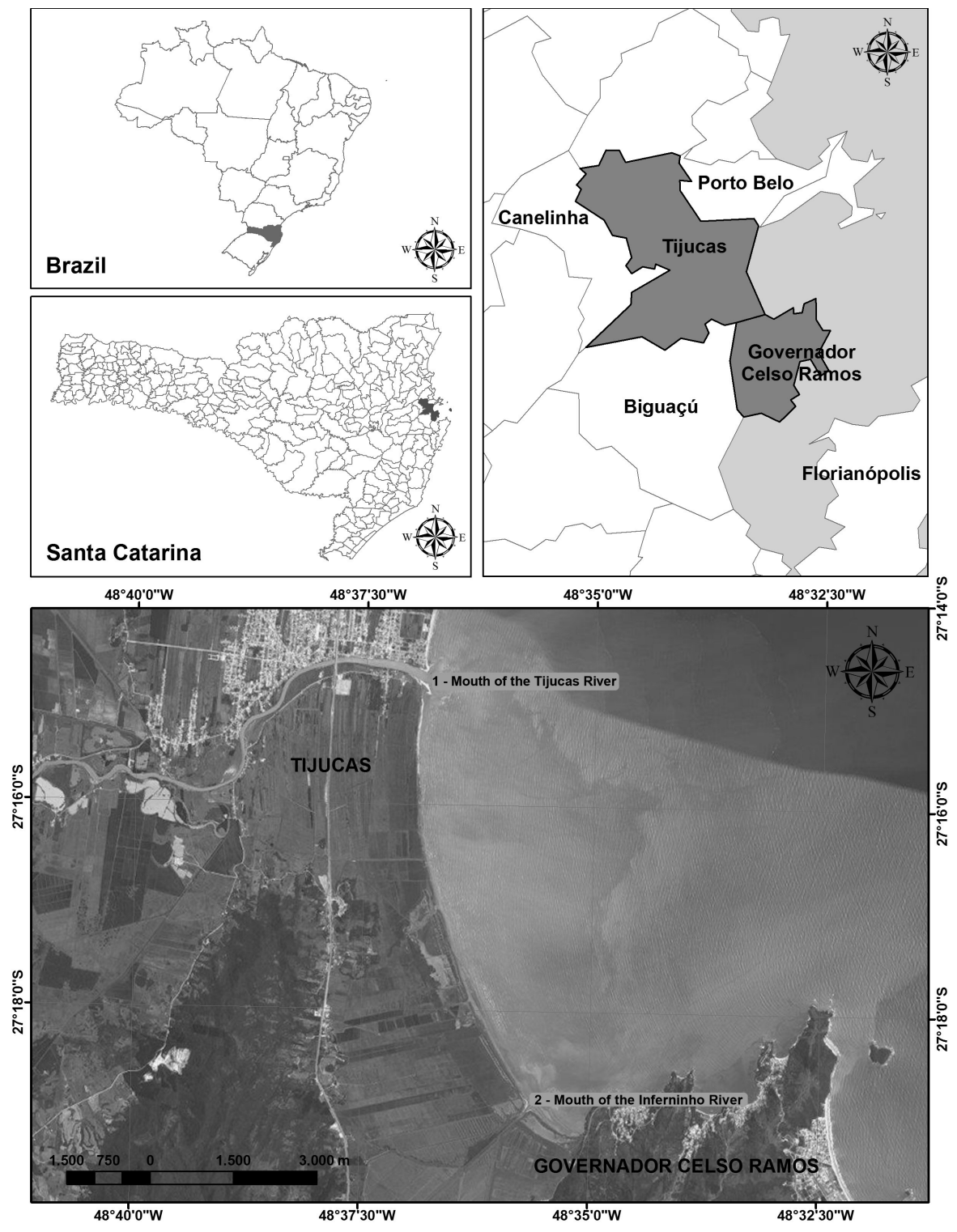

Figure 1. Location of sampling areas at the mouths of the rivers Tijucas (1) and Inferninho (2), coast of Santa Catarina, Brazil.

Climatológicos/Laboratório de Geoprocessamento e Sensoriamento Remoto - UNIVALI).

\subsection{Data analysis}

The average number of individuals per month was adopted as the standard measure of abundance (Branco, 2000). The non-parametric analysis of variance test (Kruskal-Wallis) $(\mathrm{p}<0.05)$ was used to test behavior data by time intervals and months of observation. The frequency values of behavior performed by most frequent species were grouped using the Bray-Curtis similarity coefficient using the statistical package PAST ${ }^{\circledR}$ (Hammer et al., 2001), with 0.75 similarity groups analyzed.

The Indicator Species Analysis (Dufrêne and Legendre, 1997) was used to verify habitat preference for the species that presented $\mathrm{p}<0.05$ significance. The Canonical Correlation Analysis was used to determine the relationship between environmental variables and behavior. These analyzes used the packages "indicspecies" (De Cáceres and Jansen, 2013) and "vegan" (Oksanen et al., 2011) respectively, available in the program R ( $R$ Development Core Team, 2009).

\section{Results}

A total of 44 waterbird species, distributed in 16 families, were recorded. The most abundant species were Larus dominicanus (Lichtenstein, 1823), Nannopterum brasilianus (Gmelin, 1789), Rynchops niger Linnaeus, 1758 and Himantopus melanurus (Vieillot, 1817) (Tables 1 and 2). At Tijucas, the highest abundance average of $L$. dominicanus 


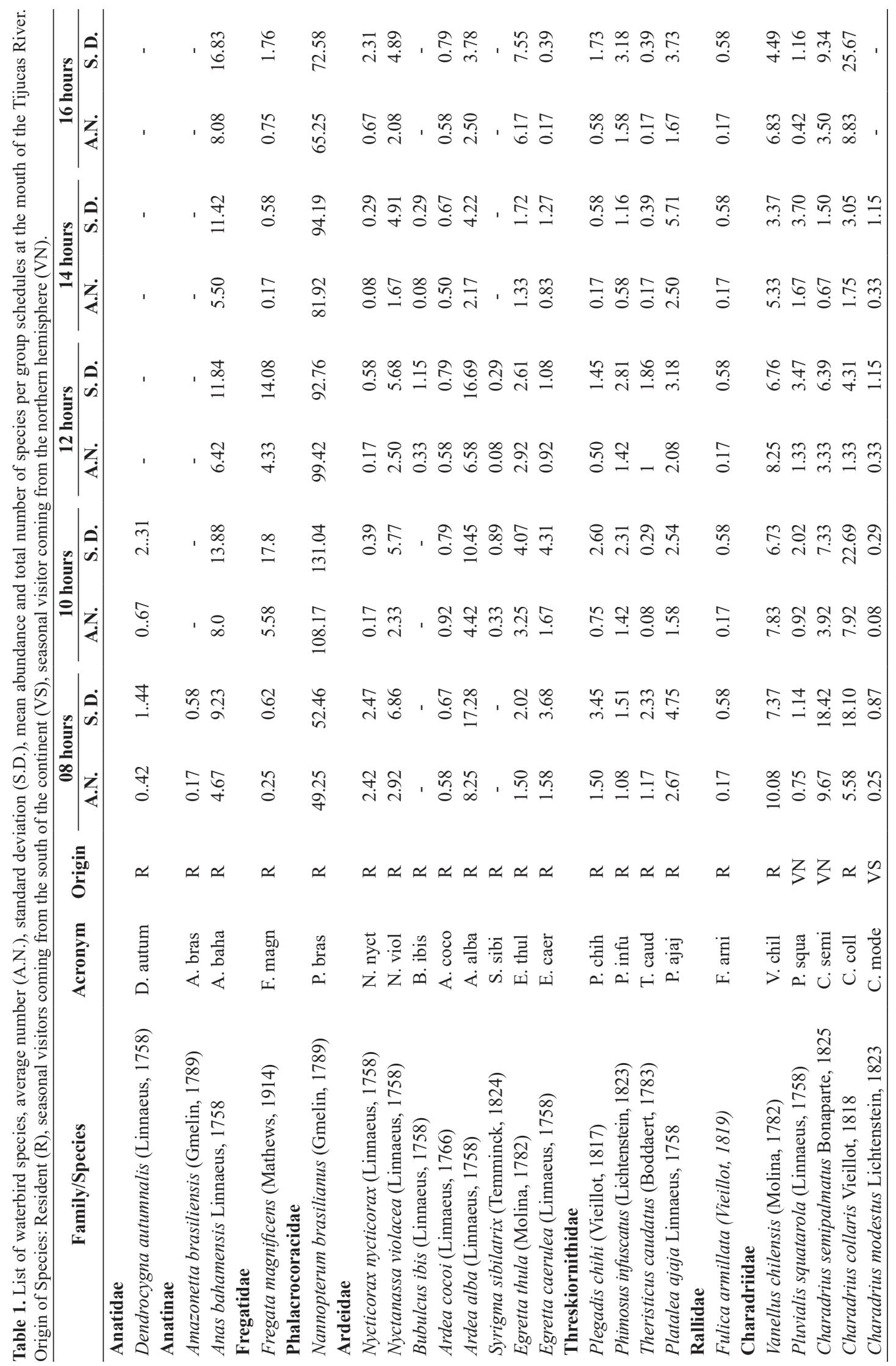




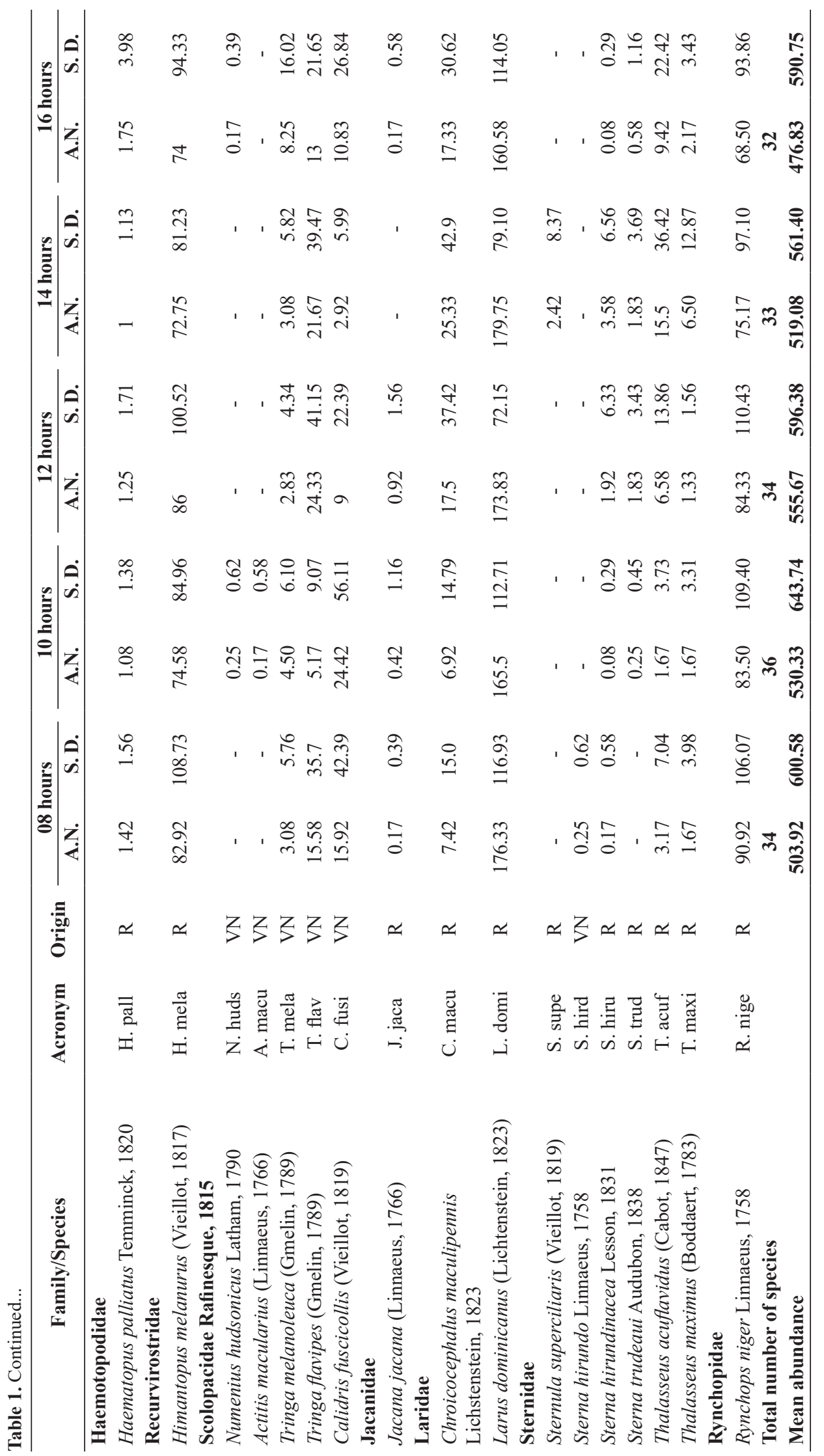




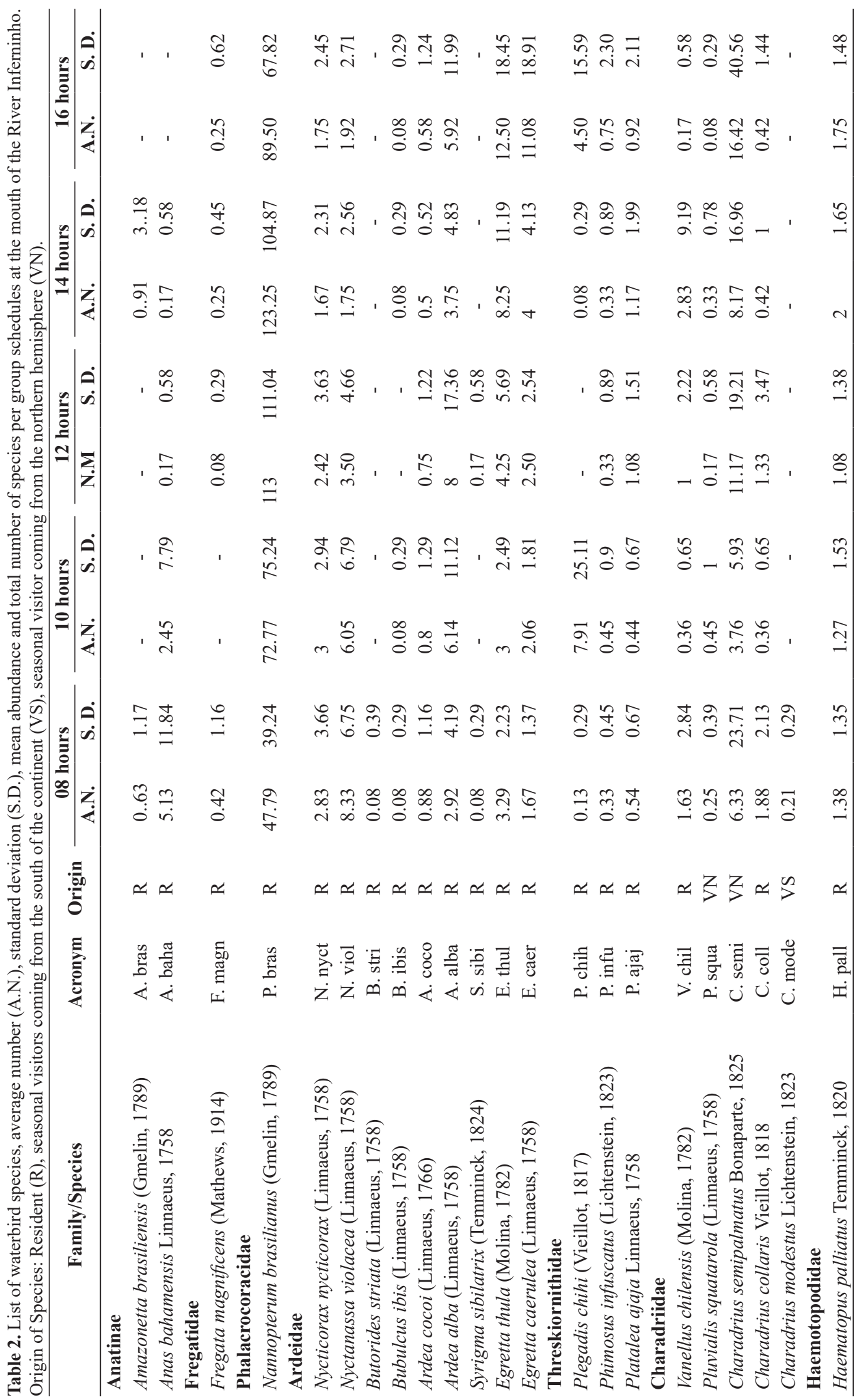




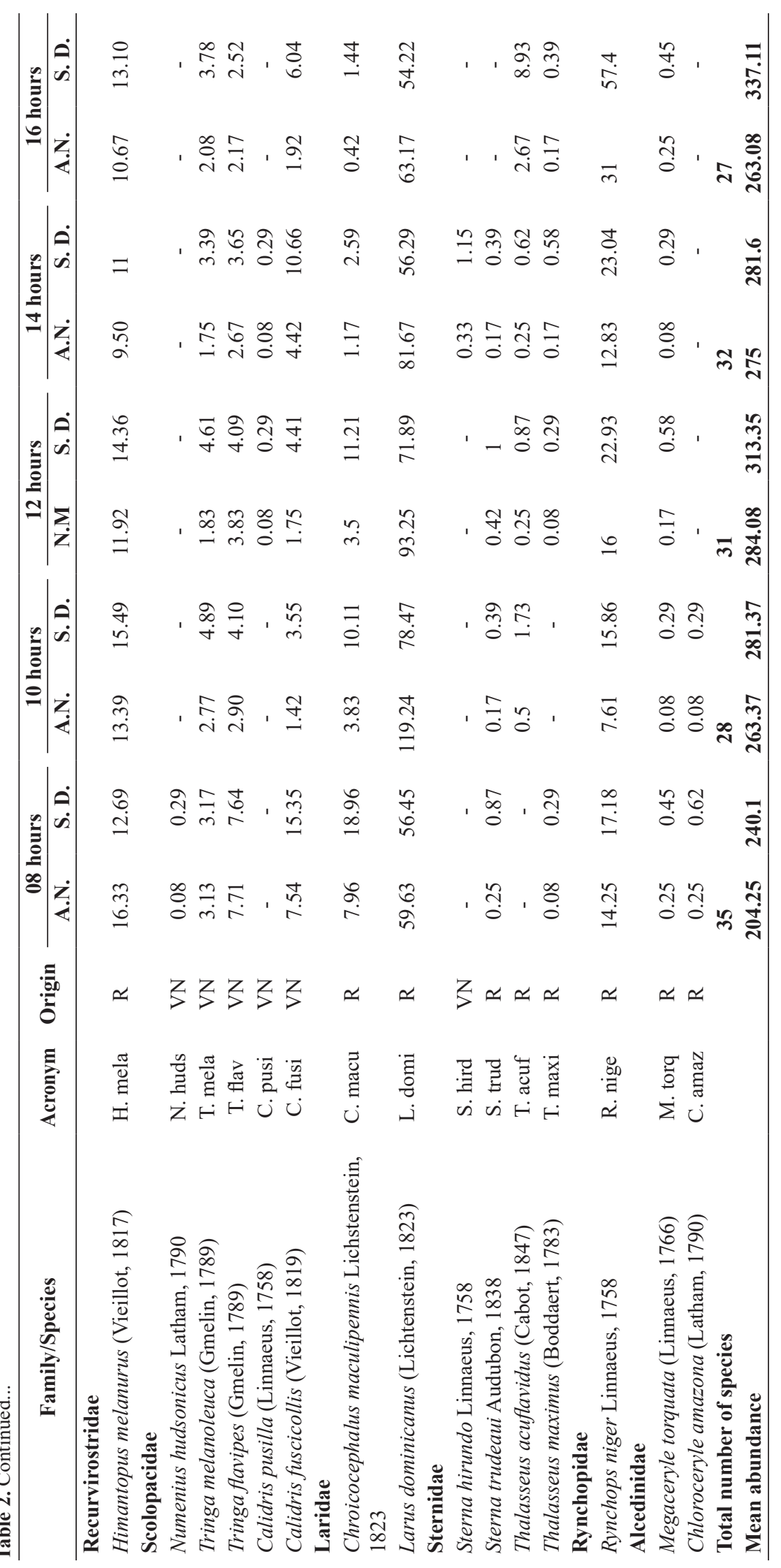


was recorded at 14:00 hours (179.75) and the lowest at 16:00 hours (160.58). At Inferninho, this species was less abundant at 8:00 hours (59.63) and more abundant around 10:00 hours (119.24), followed by a gradual decrease over the study period. In the case of $N$. brasilianus, fewer birds were recorded at 8:00 hours at the mouth of Tijucas and Inferninho, and the highest abundance at 10:00 and 14:00 hours, respectively. The mean number of $R$. niger fluctuated between 90.92 (8:00 hours) and 68.5 (16:00 hours) observations at Tijucas; and between 7.61 (10:00 hours) and 31 (16:00 hours) at Inferninho, with lower values occurring around 14: 00 hours. While the highest abundance averages of $H$. melanurus occurred between 12:00 hours (86) at the mouth of the Tijucas River and 8:00 hours (16.33) at the mouth of Inferninho, the lowest were observed at 14:00 hours in the two areas (Tables 1 and 2).

In both areas, a gradual increase in the average number of birds was recorded until 12:00 hours $($ Tijucas $=555.67$, Inferninho $=284.04)$, followed by a decrease starting 14: 00 hours. At the mouth of the Inferninho River the average value of Egretta thula Molina (1782) and Ardea alba Linnaeus 1758, unlike other species, increased at 16:00 hours due to the landing of birds which were on their way to a dormitory near the mouth of the river (Tables 1 and 2). The non-parametric analysis of variance (Kruskal-Wallis) indicated no significant difference in behavior between the sampling intervals at Tijucas $(\mathrm{KW}=0.1966 ; \mathrm{p}=0.9900)$ and Inferninho river $(\mathrm{KW}=0.0822 ; \mathrm{p}=0.9999)$. There were also no significant differences between months of sampling (Tijucas: $\mathrm{KW}=5.205$, $\mathrm{p}=0.9208$, Inferninho: $\mathrm{KW}=1.715, \mathrm{p}=0.9993$ ).

The most frequently observed behaviors were resting (61.1\% at Tijucas and $64.8 \%$ at Inferninho) and foraging ( $26.3 \%$ and $24.3 \%$, respectively), followed by plumage maintenance (11, $8 \%$ and $10.5 \%$ ) (Figure 2). Three distinct species clusters were formed in both areas, based on the frequency of similar behaviors. In groups T1 and I1, the most common activity was resting; in groups $\mathrm{T} 3$ and $\mathrm{I} 3$, foraging, and in groups T2 and I2, both activities were common, with a prevalence of foraging in both locations; plumage maintenance activities were more frequent in groups T1 and I1 (Figures 3 and 4).

Although socialization as an activity was not significant in either group ( $0.8 \%$ at Tijucas and $0.4 \%$ at Inferninho) (Figure 2), interspecific behaviors of aggression and cleptoparasitism of $L$. dominicanus towards Chroicocephalus maculipennis Lichstenstein, 1823 and Coragyps atratus (Bechstein, 1793) were observed. Egretta thula and E. caerulea (Linnaeus, 1758) displayed agonistic behavior. Vanellus chilensis (Molina, 1782) presented frequent defensive behavior and interspecific aggression, particularly directed at the raptors Caracara plancus (Miller, 1777) and C. atratus.

L. dominicanus, C. maculipennis, N. brasilianus, R. niger and A. alba were observed resting for most of the time in both areas. Charadrius semipalmatus (Bonaparte, 1825), Tringa flavipes (Gmelin, 1789), Tringa melanoleuca

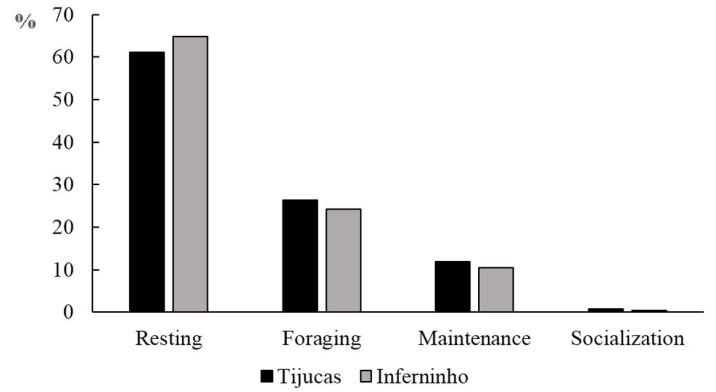

Figure 2. Frequency of recording of behaviors (rest, feeding, maintenance, socialization) presented by waterbird in the mouths of the Tijucas and Inferninho rivers.

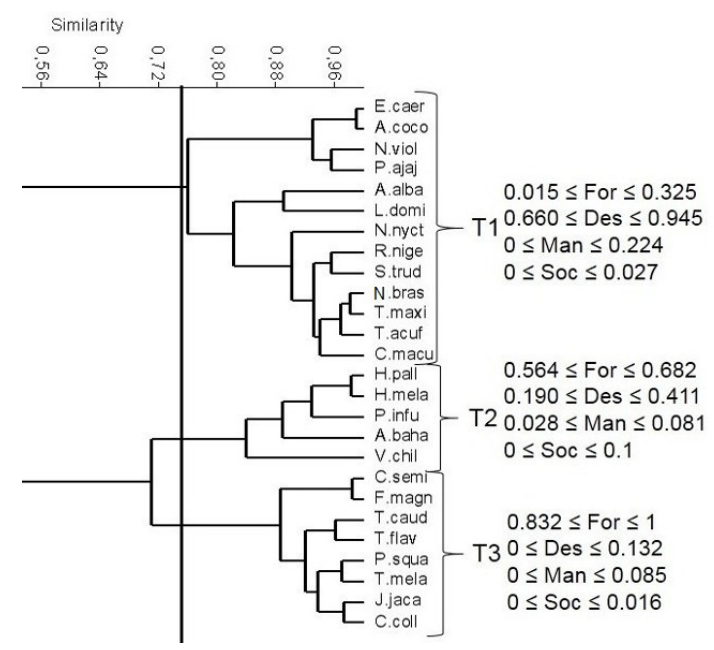

Figure 3. Similarity (Bray-Curtis) ratio (T1, T2 and T3) of the most common species and behaviors found: Foraging (For); Rest (Des); Plumage Maintenance (Man) and Socialization (Soc) at the mouth of the Tijucas River.

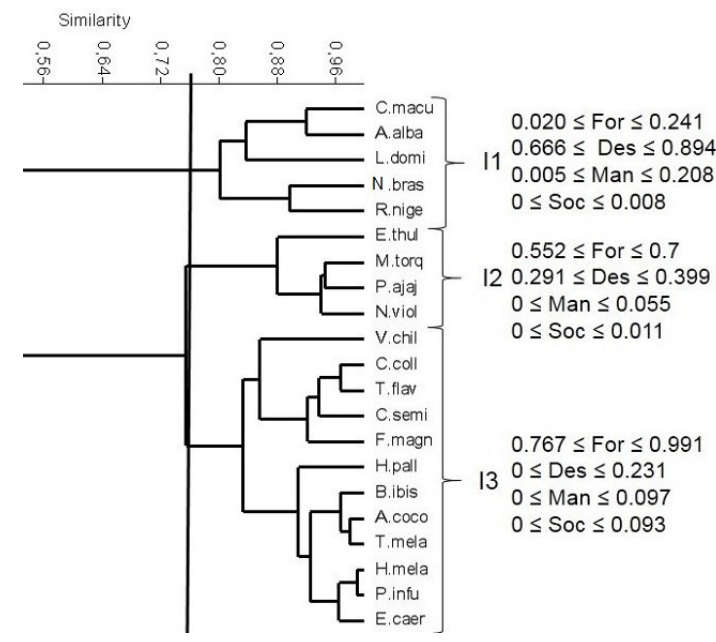

Figure 4. Similarity (Bray-Curtis) ratio (I1, I2 e I3) of the most common species and behaviors found: Foraging (For); Rest (Des); Plumage Maintenance (Man) and Socialization (Soc) at the mouth of the river Inferninho. 
(Gmelin, 1789), Charadrius collaris (Vieillot, 1818) and Fregata magnificens (Mathews, 1914) were often seen feeding. H. Melanurus, on the other hand, presented both behaviors at Tijucas and more constant foraging at the mouth of Inferninho River.

The Species Indicator Analysis showed that 17 species were associated with only one microhabitat, eight had a preference for two, four species were associated with three and one was associated with four different microhabitats (Table 3). Large clusters of N. brasilianus, L. dominicanus, $R$. niger, Thalasseus sp. and Sterna sp. formed heterospecific groups often seen resting on superlitoral. The midlitoral grouped most migratory species that were observed foraging, while the species associated with midlitoral and superlitoral were seen feeding in the first microhabitat and resting in the second. Birds that were associated with pastures were present only at the mouth of the Tijucas River, while this association was not found at the mouth of the Inferninho River, where only $V$. chilensis was found using this microhabitat. The marshes were dry from January to April at the two study areas, and the birds, which had been commonly found there, were observed foraging on the midlitoral in this period. In the coastal marine area, the species selected in the Species Indicator Analysis were often observed foraging (Table 3 ).

Individuals from the following families responded to human presence: Laridea, Rynchopidea, Phalacrocoracidae and Sternidae. For example, they abandoned their resting place when boats approached, or simply walked about $30 \mathrm{~m}$, returning to their location occupied previously after the interaction.

The total variance explained by the first two axes of the Canonical Correlation Analysis was of $99.5 \%$ (Figure 5). The first axis presented $75.35 \%$ of explicability and the second axis presented $24.26 \%$ of explicability. The environmental variables temperature, precipitation and tidal height were significant $(\mathrm{p}=0.025 ; \mathrm{p}=0.035$; $\mathrm{p}=0.002$, respectively). The results of this test showed that only the resting activity was more frequent when the tide was higher, while socialization, plumage maintenance and foraging were more present during low tides. Resting activity was also positively associated with higher temperatures.

Table 3. Species selected as indicators for the studied microhabitats, indicator value and value $\mathrm{P}<0.05$.

\begin{tabular}{|c|c|c|c|}
\hline Microhabitat & Species & $\begin{array}{c}\begin{array}{c}\text { Indicator } \\
\text { value }\end{array} \\
\end{array}$ & P-value \\
\hline \multirow[t]{7}{*}{ Midlitoral } & Charadrius collaris & 0.757 & 0.005 \\
\hline & Ardea cocoi & 0.754 & 0.005 \\
\hline & Charadrius semipalmatus & 0.727 & 0.005 \\
\hline & Tringa melanoleuca & 0.642 & 0.005 \\
\hline & Anas bahamensis & 0.515 & 0.005 \\
\hline & Calidris fuscicollis & 0.493 & 0.005 \\
\hline & Pluvialis squatarola & 0.491 & 0.010 \\
\hline \multirow[t]{5}{*}{ Superlitoral } & Nannopterum braslianus & 0.954 & 0.005 \\
\hline & Nycticorax nycticorax & 0.741 & 0.005 \\
\hline & Thalasseus maximus & 0.586 & 0.005 \\
\hline & Thalasseus acuflavidus & 0.551 & 0.005 \\
\hline & Sterna hirundinacea & 0.405 & 0.020 \\
\hline \multirow[t]{2}{*}{ Inner bursting area } & Fregata magnificens & 0.612 & 0.005 \\
\hline & Megaceryle torquata & 0.447 & 0.005 \\
\hline \multirow[t]{3}{*}{ Pasture área } & Theristicus caudatus & 0.500 & 0.005 \\
\hline & Jacana jacana & 0.488 & 0.005 \\
\hline & Syrigma sibilatrix & 0.354 & 0.050 \\
\hline \multirow[t]{5}{*}{ Superlitoral/Midlitoral } & Larus dominicanus & 0.994 & 0.005 \\
\hline & Egretta thula & 0.909 & 0.005 \\
\hline & Ardea alba & 0.836 & 0.005 \\
\hline & Egretta caerulea & 0.683 & 0.005 \\
\hline & Platalea ajaja & 0.533 & 0.025 \\
\hline \multirow[t]{2}{*}{ Midlitoral / Marsh } & Himantopus melanurus & 0.806 & 0.005 \\
\hline & Tringa flavipes & 0.661 & 0.005 \\
\hline Superlitoral / Inner bursting area & Rynchops niger & 0.697 & 0.005 \\
\hline \multirow[t]{2}{*}{ Midlitoral / Superlitoral / Marsh } & Haematopus palliatus & 0.695 & 0.005 \\
\hline & Chroicocephalus maculipennis & 0.601 & 0.005 \\
\hline \multirow[t]{2}{*}{ Midlitoral / Superlitoral / Pasture area } & Nyctanassa violácea & 0.554 & 0.040 \\
\hline & Phimosus infuscatus & 0.524 & 0.015 \\
\hline Midlitoral / Superlitoral / Marsh / Pasture area & Vanelus chilensis & 0.652 & 0.005 \\
\hline
\end{tabular}




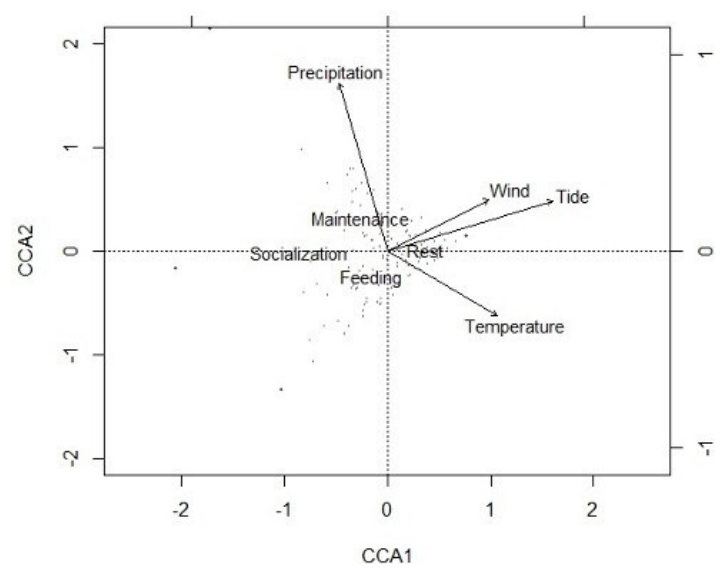

Figure 5. Canonical Correspondence Analysis (CCA) relating the behaviors presented by the aquatic birds with the environmental variables, in the mouths of the river Tijucas and Inferninho, Santa Catarina. The first axis presents (CCA1) an explanability of $75.35 \%$ and the second axis (CCA2) of $24.16 \%$.

\section{Discussion}

The distribution of individuals throughout the day was similar to that obtained by Manoel et al. (2011) at Saco da Fazenda, where the maximum relative abundance was at 14:00 hours and started to drop at 16:00 hours, which indicates birds leaving to their dorms (Branco, 2000; Ebert and Branco, 2009). The small difference in abundance and number of species between the recorded time intervals suggest that the sampled areas may be used as feeding sites throughout the day, since the abundance of prey influences the distribution of species (Hicklin and Smith, 1984; Kalejta and Hockey, 1994) and multispecific resting groups are concentrated in foraging areas (Warnock et al., 2001; Cardoso, 2011).

The largest heterospecific flocks recorded by Moraes and Krul (1995) on the coast of Paraná had an average number of 58 birds, about three times lower than the average of the groups formed by $N$. brasilianus and L. dominicanus at the mouth of the Tijucas River. The heterospecific grouping of birds for foraging, resting, migration and nesting helps to protect individuals (Moraes and Krul, 1995; Olmos and Silva, 2003; Barbieri, 2008), once predator detection is higher the larger the group (Burger and Gochfeld, 1988; Moraes and Krul, 1995; Manoel et al., 2011). Furthermore, the composition and size of groups can be influenced by seasonality and the presence of migratory species (Maldonado-Coelho and Marini, 2003).

In general, the migratory birds registered in this work, specially the members of Scolopacidae and Charadriidae, were observed foraging on benthic invertebrates in mud flats off the Brazilian coast (Barbieri and Mendonça, 2005; Barbieri et al., 2013; Silva and Rodrigues, 2015).

As demonstrated in this work, mixed flocks of Charadriidae (Nóbrega et al., 2015) and Scolopacidae were commonly observed feeding; while heterospecific groups of Sternidae, Laridae, Rynchopidae and Phalacrocoracidae were sighted when resting in coastal environments, being this oberservation corroborated by Moraes and Krul (1995), Branco (2002) and Ebert et al. (2014). The daily behavioral pattern of the birds in the areas investigated was similar to that found by Ntiamoa-Baidu et al. (1998) in coastal lagoons in Ghana and by Manoel et al. (2011) at Saco da Fazenda Santa Catarina, Brazil.

The highest frequency of foraging species in midlitoral may be associated with prey availability, visibility, tactile skills, water depth and composition of the substrate, suggesting that the choice of microhabitats is not random (Botton, 1984; Maccarone and Brzorad, 2005). Additionally, there may be interaction among species that forage the leftovers of artisanal fisheries (Branco, 2007; Ebert et al., 2014).

Some of the recorded species associated with midlitoral could also be found in other microhabitats, as noted by Cardoso (2011), once the tidal range presents abundance of aquatic invertebrates (Warnock et al., 2001; Ribeiro et al., 2004; Granadeiro et al., 2006; Cardoso, 2011), also demonstrated by the analysis of environmental variables. In addition to this variable, temperature and intensity of light also regulate the occurrence of activities and facilitate the occupation and abandonment of foraging sites (Ntiamoa-Baidu et al., 1998; Shimada, 2002).

The concentration of species that were frequently resting, such as $N$. brasilianus, L. dominicanus, Thalasseus sp. and Sterna hirundinacea in the sandbanks, was also recorded in the Laguna de Ilha Comprida (Delchiaro, 2012) and Paraná (Moraes and Krul, 1995). These microhabitas were not favorable to foraging, but are located near points with high presence of prey (Callisto et al., 2002; Leite et al., 2003) and are extensive, allowing for the formation of numerous groups. Similarly, the concentration of migratory species of Scolopacidae and Charadriidae, feeding in midlitoral, has also been recorded in other parts of the Brazilian coast (Sick, 1997; Barbieri et al., 2000; Barbieri and Mendonça, 2005; Cardoso, 2011). This behavior enables the accumulation of sufficient energy to return to nesting sites in the Northern Hemisphere and contributes to the reproductive success of the species (Davison and Evans, 1988; Barbieri et al., 2000).

The number of microhabitats to which the species were associated reflects their plasticity, so the species that were associated with only one microhabitat were considered more specialists, while those that were related to more than one could be considered generalist in lower or higher degree. Although intraspecific competition for resources is more recurrent, interspecific competition may occur and often through the defense of territories (Accordi and Hartz, 2006; Krebs and Davies, 1996).

The negative relation between temperature and foraging activity indicates that this variable is associated with thermoregulation, since at very high temperatures the food intake is reduced, lowering the heat produced in the chemical reactions that generate heat caused by feeding (Takashi et al., 2009). In addition to these variables, light 
intensity can also regulate foraging and induce occupations and abandonment of feeding areas (Ntiamoa-Baidu et al., 1998, Shimada 2002). The negative association between tidal height and foraging is related to the inability of species of reduced sizes to remain in an area during an increased tide (Zanin et al., 2009; Sebastián-González and Green, 2014) as well as the difficulty even for larger species to catch prey (Gawlik, 2002; Almeida et al., 2017).

The number of species found in this study suggest that the diversity of microhabitats in the areas allows the coexistence of species that use similar foraging resources, as well as indicates a larger range of resources for different species to maintain their daily activities (Almeida et al., 2017). The heterogeneity of microhabitats found in an area may reduce intra and interspecific competition, offering different possibilities to different species (Snyder and Chesson, 2003).

This study allowed a broader understanding of the role of waterbirds in estuarine environments, taking the example of the mouths of the rivers Tijucas and Inferninho, highlighting the conservation value of these areas as providers of microhabitats with resources for their activities throughout the day. In addition, these areas also provide rest and feeding places for migratory birds, providing opportunities for them to perform their movements properly. The particularities of the ecosystem physiognomy, as well as its environmental heterogeneity, demonstrate the importance of these areas for the maintenance of waterbirds.

\section{Acknowledgements}

This research was partialy financed by Coordenação de Aperfeiçoamento de Pessoal de Nível Superior (CAPES), through a master's scholarship to Barbara Rubert; by CNPq through a productivity grant to Joaquim Olinto Branco, and had the support from the Laboratório de Zoologia do Centro de Ciências Tecnológicas da Terra e do Mar, UNIVALI.

\section{References}

ACCORDI, I.A. and HARTZ, S.M., 2006. Distribuição espacial e sazonal da avifauna em uma área úmida do sul do Brasil. Revista Brasileira de Ornitologia, vol. 14, no. 2, pp. 117-135.

ALMEIDA, B.A., GIMENES, R.D. and ANJOS, L., 2017. Wading bird functional diversity in a floodplain: influence of habitat type and hydrological cycle. Austral Ecology, vol. 42, no. 1, pp. 84-93. http://dx.doi.org/10.1111/aec.12403.

ALTMANN, J., 1974. Observational study of behavior: sampling methods. Behaviour, vol. 49, no. 3, pp. 227-267. http://dx.doi. org/10.1163/156853974X00534. PMid:4597405.

AMEZAGA, J.M., SANTAMARIA, L. and GREEN, A.J., 2002. Biotic wetland connectivity: supporting a new approach for wetland policy. Acta Oecologica, vol. 23, no. 3, pp. 213-222. http://dx.doi.org/10.1016/S1146-609X(02)01152-9.

ARAÚJO, H.F.P., RODRIGUES, R.C. and NISHIDA, A.K., 2006. Composição da avifauna em complexos estuarinos no estado da Paraíba, Brasil. Revista Brasileira de Ornitologia, vol. 14, no. 3, pp. 249-259.
ARENGO, F. and BALDASSARRE, G.A., 1999. Resource variability and conservation of american flamingos in coastal wetlands of Yucatan, Mexico. The Journal of Wildlife Management, vol. 63, no. 4, pp. 1201-1212. http://dx.doi.org/10.2307/3802838.

BARBIERI, E. and MENDONÇA, J.T., 2005. Distribution and abundance of Charadridae at Ilha Comprida, São Paulo State, Brazil. Journal of Coastal Research, vol. 21, no. 2, pp. e1-e10. http://dx.doi.org/10.2112/04-0160.1.

BARBIERI, E. and PINNA, F.V., 2005. Distribuição da Batuírade-coleira (Charadrius collaris) durante o período de 1999 a 2001 na praia da Ilha Comprida. Revista Brasileira de Ornitologia, vol. 13 , no. 2 , pp. 25-31.

BARBIERI, E., 2008. Diversidade da dieta e do comportamento do Gaivotão Antártico (Larus dominicanus) na Península Keller, Ilha Rei George, Shetland do Sul. O Mundo da Saúde, vol. 32, no. 3, pp. 302-307. http://dx.doi.org/10.15343/0104-7809.2008323302307.

BARBIERI, E., DELCHIARO, R.T.C. and BRANCO, J.O., 2013. Flutuações mensais na abundancia dos Charadriidae e Scolopacidae da praia da Ilha comprida, São Paulo, Brasil. Biota Neotropica, vol. 13, no. 3, pp. 268-277. http://dx.doi.org/10.1590/ S1676-06032013000300029.

BARBIERI, E., MENDONÇA, J.T. and XAVIER, S.C., 2000. Distribuição da batuíra-de-bando (Charadrius semipalmatus) ao longo do ano de 1999 na praia da ilha comprida. Notas Técnicas da FACIMAR, vol. 4, pp. 69-76.

BARBIERI, E., MENDONÇA, J.T. and XAVIER, S.C., 2003. Importance of Ilha Comprida (São Paulo State, Brazil) for the Sanderlings (Calidris alba) migration. Journal of Coastal Research, vol. 35 , pp. 440-445.

BLANCO, D.E., 1999 [viewed 16 September 2015]. Los humedales como habitat de aves acuaticas. Montevideo: UNESCO. Available from: http://www.unesco.org.uy/phi/aguayeducacion/fileadmin/ ciencias\%20naturales/mab/13.pdf

BOTTON, M.L., 1984. Effects of laughing gull and shorebird predation on the intertidal fauna at Cape May, New Jersey. Estuarine, Coastal and Shelf Science, vol. 18, no. 2, pp. 209-220. http://dx.doi.org/10.1016/0272-7714(84)90107-0.

BRANCO, J.O., 2000. Avifauna associada ao estuário do Saco da Fazenda, Itajaí, SC. Revista Brasileira de Zoologia, vol. 17, no. 2, pp. 387-394. http://dx.doi.org/10.1590/S0101-81752000000200009.

BRANCO, J.O., 2002. Flutuações sazonais na abundância de Nannopeterum brasilianus no estuário do Saco da Fazenda, Itajaí, SC. Revista Brasileira de Zoologia, vol. 19, no. 4, pp. 1057-1062. http://dx.doi.org/10.1590/S0101-81752002000400010.

BRANCO, J.O., 2007. Avifauna aquática do Saco da Fazenda (Itajaí, Santa Catarina, Brasil): uma década de monitoramento. Revista Brasileira de Zoologia, vol. 24, no. 4, pp. 873-882. http:// dx.doi.org/10.1590/S0101-81752007000400003.

BRANCO, J.O., EVANGELISTA, C.L., LUNARDON-BRANCO, M.J., AZEVEDO JÚNIOR S.M. and LARRAZÁBAL, M.E., 2009. Atividade diária de Phalacrocorax brasilianus (Aves, Phalacrocoracidae), na região do Saco da Fazenda, Itajaí, SC, Brasil. Ornithologia, vol. 3, no. 2, pp. 73-82.

BRASIL. Instituto Brasileiro do Meio Ambiente e Recursos Renováveis - IBAMA, 2004. Portaria IBAMA $n^{\circ} 51$, de 10 de maio de 2004. Aprova o conselho consultivo da Reserva Biológica Marinha do Arvoredo [online]. Diário Oficial da República Federativa do Brasil, Brasilia, 11 maio. 
BURGER, J. and GOCHFELD, M., 1988. Nest-site Selection and temporal patterns in habitat use of Roseate and Common Terns. The Auk, vol. 105, no. 3, pp. 433-438. http://dx.doi.org/10.1093/ auk/105.3.433.

BURGER, J. and GOCHFELD, M., 1991. Human activity influence and diurnal and nocturnal foraging of sanderlings (Calidris alba). The Condor, vol. 93, no. 2, pp. 259-265. http://dx.doi. org/10.2307/1368941.

CALLISTO, M., MORENO, P., GONÇALVES JÚNIOR, J.F., LEAL, J.J.F. and ESTEVES, F.A., 2002. Diversiy and biomass of chironomidae (diptera) larvae in an impacted coastal lagoon in Rio de Janeiro, Brazil. Brazilian Journal of Biology = Revista Brasileira de Biologia, vol. 62, no. 1, pp. 77-84. http://dx.doi.org/10.1590/ S1519-69842002000100010. PMid:12185926.

CARDOSO, T.A.L., 2011. Distribuição de aves limícolas migratórias (Charadriidae e Scolopacidae) em estuários: preferência de hábitats e estrutura das assembleias. João Pessoa: Universidade Estadual da Paraíba. Dissertação de Mestrado em Ecologia e Conservação.

CASTRO, P. and HUBER, M.E., 2012. Biologia marinha. 8. ed. Porto Alegre: AMGH, $480 \mathrm{p}$.

CESTARI, C., 2008. O uso de praias arenosas com diferentes concentrações humanas por espécies de aves limícolas (Charadriidae e Scolopacidae) neárticas no sudeste do Brasil. Biota Neotropica, vol. 8, no. 4, pp. 83-88. http://dx.doi.org/10.1590/S167606032008000400007.

COMITÊ BRASILEIRO DE REGISTROS ORNITOLÓGICOS - CBRO, 2015 [viewed 15 May 2019]. Listas das aves do Brasil [online]. Available from: http://www.cbro.org.br/

DAVISON, N. and EVANS, P., 1988. Prebreeding accumulation of fat and muscle protein by Artic nesting shorebirds. In: Procedings of the 19th International Ornithological Congress, 1988, Ottawa. Ottawa: University of Ottawa Press, pp. 342-352.

DE CÁCERES, M. and JANSEN, F., 2013 [viewed 16 September 2015]. Studying the statistical relationship between species and groups of sites. $R$ Package version 1.6.7 [online]. Available from: http://www2.uaem.mx/r-mirror/web/packages/indicspecies/ indicspecies.pdf

DELCHIARO, R.T.C., 2012. Aves associadas ao ambiente aquático na Laguna da Ilha Comprida, SP, Brasil. São Paulo: Universidade de São Paulo, 96 p. Dissertação de Mestrado em Ciências.

DUFRÊNE, M. and LEGENDRE, P., 1997. Species assemblages and indicator species: the need for a flexible asymmetrical approach. Ecological Monographs, vol. 67, no. 3, pp. 345-366. http://dx.doi. org/10.2307/2963459.

EBERT, L.A. and BRANCO, J.O., 2009. Variação sazonal na abundância de Larus dominicanus (Aves, Laridae) no Saco da Fazenda, Itajaí, Santa Catarina. Iheringia: Série Zoologia, vol. 99, no. 4, pp. 437-441. http://dx.doi.org/10.1590/S0073-47212009000400015.

EBERT, L.A., BRANCO, J.O. and BARBIERI, E., 2014. Daily activities of Larus dominicanus (Lichtenstein 1823) at Saco da Fazenda, Itajaí-Açu river estuary, Itajai, SC. Pan-American Journal of Aquatic Sciences, vol. 9, no. 3, pp. 199-206.

ELLIOTT, M., WHITFIELD, A.K., POTTER, I.C., BLABER, S.J.M., CYRUS, D.P., NORDLIE, F.G. and HARRISON, T.D., 2007. The guild approach to categorizing estuarine fish assemblages: a global review. Fish, vol. 8, no. 3, pp. 241-268. http://dx.doi. org/10.1111/j.1467-2679.2007.00253.x.
FASOLA, M. and CANOVA, L., 1993. Diel acitivity of resident and immigrant waterbirds at Lake Turkana, Kenya. The Ibis, vol. 135, no. 4, pp. 442-450. http://dx.doi.org/10.1111/j.1474919X.1993.tb02117.x.

GAWLIK, D.E., 2002. The effects of prey availability on the numerical responses of wading birds. Ecological Monographs, vol. 72, no. 3, pp. 329-346. http://dx.doi.org/10.1890/00129615(2002)072[0329:TEOPAO]2.0.CO;2.

GHIZONI JUNIOR, I.R. and PIACENTINI, V Q., 2010. The Andean Flamingo Phoenicoparrus andinus (Philippi, 1854) in southern Brazil: is it a vagant? Revista Brasileira de Ornitologia, vol. 3 , no. 18 , pp. $263-266$.

GRANADEIRO, J.P., DIAS, M.P., MARTINS, R.C. and PALMEIRIM, J.M., 2006. Variation in numbers and behaviour of waders during the tidal cycle: implications for the use of estuarine sediment flats. Acta Oecologica, vol. 29, no. 3, pp. 293-300. http://dx.doi. org/10.1016/j.actao.2005.11.008.

HAIG, S.M., MEHLMAN, D.W. and ORING, L.W., 1998. Avian movements and wetland connectivity in landscape conservation. Conservation Biology, vol. 12, no. 4, pp. 749-758. http://dx.doi. org/10.1046/j.1523-1739.1998.97102.x.

HAMMER, Ø., HARPER, D.A.T. and RYAN, P.D., 2001. PAST: palaeontological statistics. Palaeontologia Electronica, vol. 4, no. 1, pp. 1-9.

HASTIE, B.F. and SMITH, S.D.A., 2006. Benthic macrofaunal communities in intermitente estuaries during a drought: comparisons with permanently open estuaries. Journal of Experimental Marine Biology and Ecology, vol. 330, no. 1, pp. 356-367. http://dx.doi. org/10.1016/j.jembe.2005.12.039.

HERCULANO, D. M., SANTOS, M.A.B. and PIGOZZO, C.M., 2013. Etograma de Flamingo-Chileno, Phoenicopterus chilensis (Phoenicopteriformes, Phoenicopteridae), em condição de cativeiro no Parque Zoobotânico Getúlio Vargas. Candombá, vol. 9, no. 1, pp. 8-21.

HICKLIN, R.W. and SMITH, P.C., 1984. Selection of foraging sites and invertebrate prey by migrant Semipalmated Sandpipers Calidris pusilla (Pallas, in Minas Basin, Bay of Fundy. Canadian Journal of Zoology, vol. 62, no. 11, pp. 2201-2210. http://dx.doi. org/10.1139/z84-321.

KALEJTA, B. and HOCKEY, P.A.R., 1994. Distribution of shorebird at the Berg river estuary, South Africa, in relation to foraging mode, food supply and environmental features. The Ibis, vol. 136, no. 2, pp. 233-239. http://dx.doi.org/10.1111/j.1474-919X.1994.tb01089.x.

KASOMA, P.M.B., 2000. Diurnal activity patterns of three heron species in Quenn Elizabeth National Park, Uganda. The Ostrich, vol. 71, no. 1, pp. 127-130. http://dx.doi.org/10.1080/00306525. 2000.9639889 .

KREBS, J.R. and DAVIES, N.B., 1996. Introdução à ecologia comportamental. São Paulo: Atheneu.

LEITE, F.P.P., TURRA, A. and SOUZA, E.C.F., 2003. Population biology and distribution of the tanaid Kalliapseudes schubarti Mañé-Garzon, 1949, in an intertidal flat in southeastern Brazil. Brazilian Journal of Biology = Revista Brasileira de Biologia, vol. 63, no. 3, pp. 469-479. http://dx.doi.org/10.1590/S151969842003000300013. PMid:14758706.

LOEBMANN, D. and VIEIRA, J.P., 2006. O impacto da pesca do camarão-rosa Farfantepenaus paulensis (Perez- Farfante, 1967) 
(Decapoda, Penaeidae) nas assembleias de peixes e siris do Parque Nacional da Lagoa do Peixe, Rio Grande do Sul, Brasil. Revista Brasileira de Zoologia, vol. 23, no. 4, pp. 1016-1028. http://dx.doi. org/10.1590/S0101-81752006000400006.

LOPES, I.F., MIÑO, C.I. and DEL LAMA, S.N., 2007. Genetic diversity and evidence of recent demographic expansion in waterbird populations from the Brazilian Pantanal. Brazilian Journal of Biology = Revista Brasileira de Biologia, vol. 67, no. 4, suppl., pp. 849-857. http://dx.doi.org/10.1590/S1519-69842007000500007. PMid:18278351.

MACCARONE, A. and BRZORAD, J., 2005. Foraging microhabitat selection by wading birds in a tidal estuary, with implications for conservation. Waterbirds, vol. 28, no. 3, pp. 383-391. http://dx.doi. org/10.1675/1524-4695(2005)028[0383:FMSBWB]2.0.CO;2.

MACCARONE, A.D. and PARSONS, K.C., 1994. Factors affecting the use of a freshwater and an estuarine foraging site by egrets and ibises during the breeding season in New York City. Colonial Waterbirds, vol. 17, no. 1, pp. 60-68. http://dx.doi. org/10.2307/1521382.

MALDONADO-COELHO, M. and MARINI, M.A., 2003. Composição de bandos mistos de aves em fragmentos de mata atlântica no sudeste do Brasil. Papéis Avulsos de Zoologia, vol. 43, no. 3, pp. 31-54. http://dx.doi.org/10.1590/S0031-10492003000300001.

MANOEL, F.C., BRANCO, J.O. and BARBIERI, E., 2011. Flutuações sazonal e diária das aves aquáticas no Saco da Fazenda, Itajaí-SC. O Mundo da Saude, vol. 35, no. 1, pp. 47-54. http:// dx.doi.org/10.15343/0104-7809.20113514754.

MEDEIROS, R.P., 2009. Possibilidades e Obstáculos á co-gestão adaptativa de sistemas pesqueiros artesanais: estudos de caso na área da Baía de Tijucas, litoral Centro-Norte do Estado de Santa Catarina. Florianópolis: Universidade Federal de Santa Catarina, 337 p. Tese de Doutorado em Sociologia Política.

MORAES, V.S. and KRUL, R., 1995. Composição e finalidades de agrupamentos heteroespecíficos de aves em ambientes naturais do Paraná e Santa Catarina. Biotemas, vol. 8, no. 2, pp. 63-73.

MORRISON, R.G., 1984. Migration systems of some new world shorebirds. In: J. BURGER and B.L. OLLA, eds. Behavior of marine animals: shorebirds: migration and forangins behavior. New York: Plenum Press, vol. 6, pp. 125-202.

NÓBREGA, P.F.A., AGUIAR, J.A.B. and FIGUEIRA, J.E.C., 2015. First records of Charadrius semipalmatus, Bonaparte 1825 (Charadriidae) and Gelochelidon nilotica Gmelin 1789 (Sternidae) in the State of Minas Gerais, Brazil. Brazilian Journal of Biology = Revista Brasileira de Biologia, vol. 75, no. 2, pp. 451-454. http:// dx.doi.org/10.1590/1519-6984.17013. PMid:26132031.

NTIAMOA-BAIDU, Y., PIERSMA, T., WIERSMA, P., POOT, M., BATTLEY, P. and GORDON, C., 1998. Water depth selection, daily feeding routines and diets of waterbirds in coastal lagoons in Ghana. The Ibis, vol. 140, no. 1, pp. 89-103. http://dx.doi. org/10.1111/j.1474-919X.1998.tb04545.x.

NUNES, P.A. and PIRATELLI,A., 2005. Comportamento de jaçanã (Jacana jacana Linnaeus, 1766) (Charadriiformes, Jacanidae) em uma lagoa urbana no município de Três Lagoas, Mato Grosso do Sul, Brasil. Atualidades Ornitológicas, vol. 126, pp. 17-34.

OKSANEN, J., BLANCHET, F.G., KINDT, R., LEGENDRE, P., MINCHIN, P.R., O'Hara, R.B., SIMPSON, G.L., SOLYMOS, P., STEVENS, M.H.H. and WAGNER, H. 2011. Vegan: Community
Ecology Package. R package version 1.178. Vienna: R Foundation for Statistical Computing.

OLMOS, F. and SILVA, R., 2003. Guará: ambiente, flora e fauna dos manguezais de Santos-Cubatão. São Paulo: Empresa das Artes.

PIMENTA, F.E., DRUMMOND, T.C.P. and LIMA, A.C., 2007. Aves aquáticas da Lagoa da Pampulha: seleção de hábitats e atividade diurna. Lundiana, vol. 8, no. 2, pp. 89-96.

R DEVELOPMENT CORE TEAM, 2009. A language and environment for statistical computing. Vienna: R Foundation for Statistical Computing.

RIBEIRO, P.D., IRIBARNE, O., NAVARRO, D. and JAUREGUY, L., 2004. Environmental heterogeneity, spatial segregation of prey, and the utilization of southwest Atlantic mudflats by migration shorebirds. The Ibis, vol. 146, no. 4, pp. 672-682. http://dx.doi. org/10.1111/j.1474-919X.2004.00301.x.

SANTA CATARINA. Gabinete de Planejamento - GAPLAN, 1986. Atlas de Santa Catarina. Florianópolis, 173 p.

SCHETTINI, C.A.F., 2002. Caracterização Física do Estuário do Rio Itajaí-açu, SC. Revista Brasileira de Recursos Hídricos, vol. 7, no. 1, pp. 123-142. http://dx.doi.org/10.21168/rbrh.v7n1.p123-142.

SCHETTINI, C.A.F., ALMEIDA, D.C., SIEGLE, E. and ALENCAR, A.C.B., 2010. A snapshot of suspended sediment and fluid mud occurrence in a mixed-energy embayment, Tijucas Bay, Brazil. GeoMarine Letters, vol. 30, no. 1, pp. 47-62. http://dx.doi.org/10.1007/ s00367-009-0152-8.

SCHREIBER, E.A. and BURGER, J., 2002. Seabirds in the marine environment. In: E.A. SCHREIBER and J. BURGER, eds. Biology of marine birds. Boca Raton: CRC Press, pp. 1-15.

SEBASTIAN-GONZALEZ, E. and GREEN, A.J., 2014. Habitat use by waterbirds in relation to pond size, water depth, and isolation. Restoration Ecology, vol. 22, no. 3, pp. 311-318.

SHIMADA, T., 2002. Daily activity pattern and habitat use of greater white-fronted geese wintering in Japan: factors of the population increase. Waterbirds, vol. 25, no. 3, pp. 371-377. http://dx.doi. org/10.1675/1524-4695(2002)025[0371:DAPAHU]2.0.CO;2.

SICK, H., 1997. Ornitologia brasileira. Rio de Janeiro: Nova Fronteira.

SILVA, L. M.R. and RODRIGUES, A.A.F., 2015. Densidade e distribuição espacial de aves limícolas em habitats de forrageio na costa amazônica brasileira. Ornithologia, vol. 8, no. 1, pp. 17-21.

SNYDER, R.E. and CHESSON, P., 2003. Local dispersal can facilitate coexistence in the presence of permanent spatial heterogeneity. Ecology Letters, vol. 6, no. 4, pp. 301-309. http:// dx.doi.org/10.1046/j.1461-0248.2003.00434.x.

STEPHENSON, T.A. and STEPHENSON, A., 1949. The universal features of zonation between tide-mark on rocky coast. British Ecological Society, vol. 37, no. 2, pp. 289-305. http://dx.doi. org/10.2307/2256610.

TAKASHI, L.S., BILLER, J.D. and TAKASHI, K.M., 2009. Bioclimatologia Zootécnica. 1. ed. Jaboticabal: Funep.

VOOREN, C.M. and BRUSQUE, L.F., 1999 [viewed 30 August 2015]. As aves do ambiente costeiro do Brasil: biodiversidade e conservação [online]. Available from: http://www.bdt.org.br/ workshop/costa/plat_continental 
WARNOCK, N., ELPHICK, C. and RUBEGA, M.A., 2001. Shorebirds in the marine environment. In: E. A. SCHREIBER and J. BURGER, eds. Biology of marine birds. Boca Raton: CRC Press, pp. 581-615.

YANG, R., WU, H., YANG, X., JIANG, W., ZUO, L. and XIANG, Z., 2007. Diurnal time budget of the black-necked crane during the breeding season. Waterbirds, vol. 30, no. 1, pp. 80-85. http:// dx.doi.org/10.1675/1524-4695(2007)030[0080:DTBOTB]2.0.CO;2.
ZANIN, G.R., TOSIN, L.F. and BARBIERI, E., 2009. Variação da avifauna, em relação ao nível da maré, no uso de um plano intermareal no Mar Pequeno, Ilha Comprida, São Paulo. Estudos de Biologia, vol. 31, no. 73, pp. 39-48. http://dx.doi.org/10.7213/reb.v31i73/75.22836.

ZHOU, B., ZHOU, L., CHEN, J., CHENG, Y. and XU, W., 2010. Diurnal time-activity budgets of wintering hooded cranes (Grus monacha) in Shengjin Lake, China. Waterbirds, vol. 33, no. 1, pp. 110-115. http://dx.doi.org/10.1675/063.033.0114. 